\title{
Preliminary results of mass-balance observations of Yala Glacier and analysis of temperature and precipitation gradients in Langtang Valley, Nepal
}

\author{
Prashant BARAL, ${ }^{1}$ Rijan B. KAYASTHA, ${ }^{1}$ Walter W. IMMERZEEL, ${ }^{2}$ \\ Niraj S. PRADHANANGA, ${ }^{1}$ Bikas C. BHATTARAI, ${ }^{1}$ Sonika SHAHI, ${ }^{1}$ Stephan GALOS, ${ }^{3}$ \\ Claudia SPRINGER, ${ }^{4}$ Sharad P. JOSHI, ${ }^{5}$ Pradeep K. MOOL ${ }^{5}$ \\ ${ }^{1}$ Himalayan Cryosphere, Climate and Disaster Research Center, Kathmandu University, Dhulikhel, Nepal \\ E-mail: prashant@student.ku.edu.np \\ ${ }^{2}$ Faculty of Geosciences, Utrecht University, Utrecht, The Netherlands \\ ${ }^{3}$ Institute of Meteorology, University of Innsbruck, Innsbruck, Austria \\ ${ }^{4}$ Central Institute for Meteorology and Geodynamics, Department of Climatology, Vienna, Austria \\ ${ }^{5}$ International Centre for Integrated Mountain Development, Lalitpur, Nepal
}

\begin{abstract}
Monitoring the glacier mass balance of summer-accumulation-type Himalayan glaciers is critical to not only assess the impact of climate change on the volume of such glaciers but also predict the downstream water availability and the global sea-level change in future. To better understand the change in meteorological parameters related to glacier mass balance and runoff in a glacierized basin and to assess the highly heterogeneous glacier responses to climate change in the Nepal Himalaya and nearby ranges, the Cryosphere Monitoring Project (CMP) carries out meteorological observations in Langtang Valley and mass-balance measurements on Yala Glacier, a debris-free glacier in the same valley. A negative annual mass balance of $-0.89 \mathrm{~m}$ w.e. and the rising equilibrium-line altitude of Yala Glacier indicate a continuation of a secular trend toward more negative mass balances. Lower temperature lapse rate during the monsoon, the effect of convective precipitation associated with mesoscale thermal circulation in the local precipitation and the occurrence of distinct diurnal cycles of temperature and precipitation at different stations in the valley are other conclusions of this comprehensive scientific study initiated by CMP which aims to yield multi-year glaciological, hydrological and meteorological observations in the glacierized Langtang River basin.
\end{abstract}

KEYWORDS: accumulation, climate change, glacier mass balance, glaciological instruments and methods, mountain glaciers

\section{INTRODUCTION}

Glaciers in the Nepal Himalaya have been recognized as an indicator of changing climate because their dimensions change in response to surrounding climatic conditions, and therefore monitoring of glaciers has been carried out worldwide (Holmlund and others, 1996; Kadota and others, 1997; Beniston 2003; Raup and others, 2007; Gardner and others, 2013). Himalayan glaciers are very vulnerable to the increase in air temperature, especially the summer-accumulationtype glaciers because of the strong negative effect on glacier mass balance (Ageta and others, 2001). For example, accelerated shrinkage of Himalayan glaciers has been reported in the past (Yamada and others, 1992; Kadota and others, 1993; Bolch and others, 2012). However, recent work has shown that glacier responses to climate change are highly heterogeneous in the Himalaya and nearby ranges (Fujita and Nuimura, 2011; Kargel and others, 2011; Bolch and others, 2012). Evaluation of glacier mass balance is not only important for regional water resources but also for global sea-level change (Fujita and others, 1998; Rignot and others, 2011; Jacob and others, 2012; Shepherd and others, 2012; Gardner and others, 2013). It is also important to monitor the mass balance of summer-accumulation-type glaciers to better understand the impact of climate change on the volume of these glaciers. With such mass-balance measurements, the downstream water availability can also be predicted for the coming years. However, there is a lack of continuous monitoring of the glacier, also without any instances of long-term mass-balance measurements. This is mainly due to difficult access to the mountains, and financial constraints. In this context, glaciological observations are being carried out on Yala Glacier by the Cryosphere Monitoring Project (CMP). Our analysis of crucially needed observational data buttresses and extends knowledge obtained about Yala Glacier by the energy-/mass-balance modeling approach of Fujita and Nuimura (2011).

Temperature and precipitation vary with space and time, thus defining the local weather and climate of any particular place. Several factors are responsible for the change in these variables. Climatically, altitudinal distribution of precipitation has been analyzed according to climatic region (Barry, 1981). The summer monsoon climate of the Nepal Himalaya, where summer precipitation exceeds winter precipitation, is considerably influenced by the Indian monsoon, and apparent seasonal variation exists in meteorological fields (Seko, 1987; Takahashi and others, 1987; Seko and Takahashi, 1991).

There is a lack of availability of sufficient hydrological and meteorological data of the high-altitude regions of the Nepal Himalaya. Regular monitoring and maintenance of the existing weather stations and other temperature and precipitation sensors is necessary for collecting hydrological 


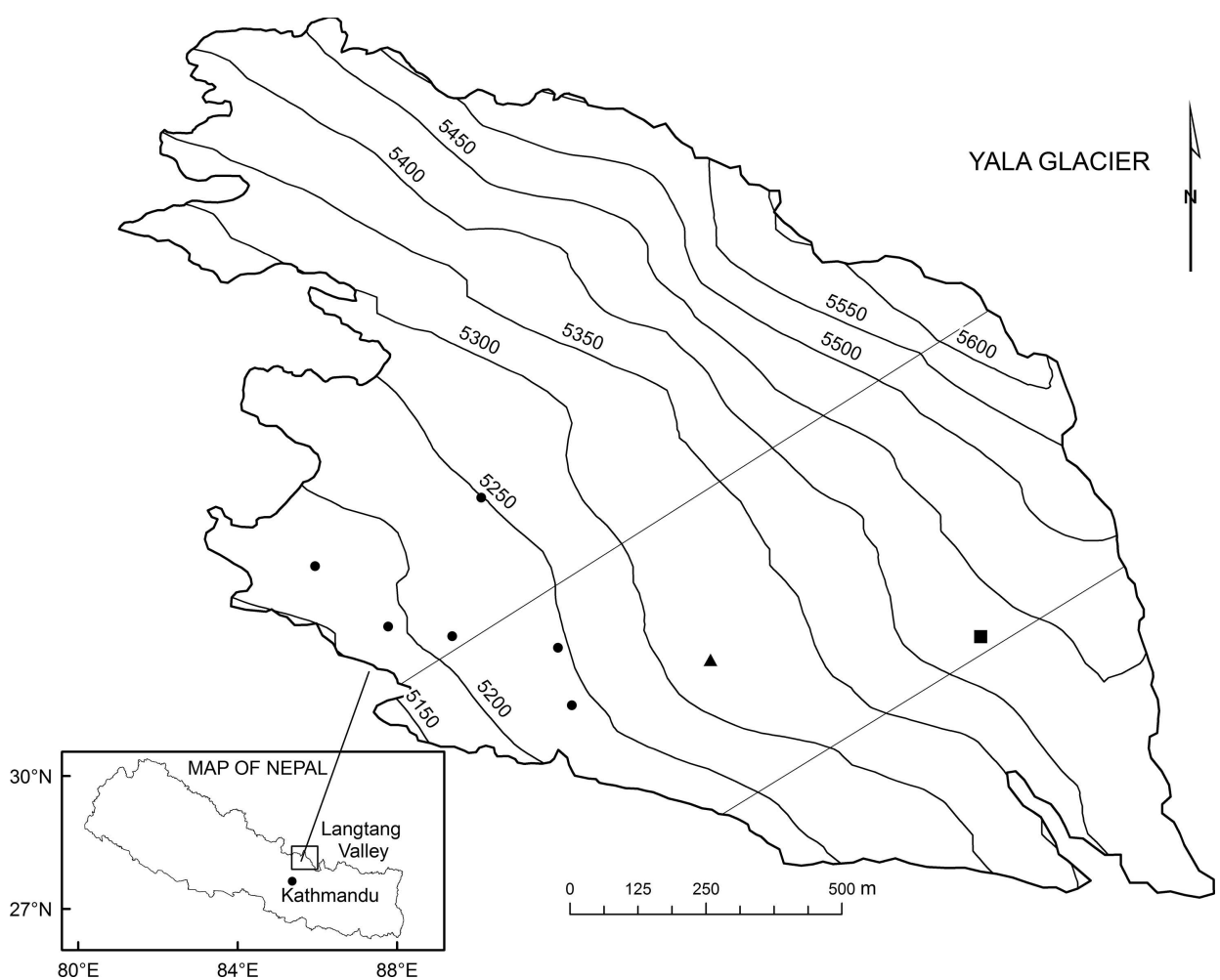

Fig. 1. Map of Nepal showing Langtang Valley and Yala Glacier (RapidEye 2010). Solid circles on Yala Glacier denote the stakes installed by the CMP for mass-balance measurements. Solid triangle and square denote Chinese and Japanese stakes respectively. The areas between the two straight lines ('transect') are assumed as the representative areas for the calculation of mass balance as considered by Fujita and others (1998).

and meteorological information in such regions. Seko (1987), Seko and Takahashi (1991), Shiraiwa and others (1992) and Ueno and others (1993) have evaluated the distribution of precipitation in the valley. However, the change in meteorological parameters related to glacier mass balance and runoff in the valley has not been studied with respect to global climate change in the recent past.

The main objective of this study is to calculate the mass balance of Yala Glacier, but while doing so, another objective is to analyze the temperature and precipitation gradients and diurnal cycles in Langtang Valley. Massbalance observations were carried out from November 2011 to November 2012, while meteorological observations are performed in the valley from May to October 2012 so as to determine the altitudinal variation of precipitation and temperature during the observation period. These measurements are, however, just the start of a comprehensive scientific study initiated by the CMP. The project aims to yield a multi-year mass-balance observation that can be of great use in determining the eventual state of the cryosphere of the Himalayan region.

\section{STUDY AREA}

Several sets of glaciological, meteorological and hydrological observations have been performed in Langtang Valley, Nepal, since 1981 (e.g. Higuchi, 1984; Watanabe and Higuchi, 1987; Yamada, 1989). The fluctuations of glaciers in Langtang Valley were reported by Kappenberger and others (1993). Snow-pit observations have been carried out at $5350 \mathrm{ma.s.l}$. in the accumulation zone of Yala Glacier, Langtang Valley (Iida and others, 1987; Ozawa, 1991). Glaciological observations of Yala Glacier were carried out in 1994 and 1996 (Fujita and others, 1998).
The study site for mass balance, Yala Glacier $\left(28^{\circ} 14^{\prime} \mathrm{N}\right.$, $85^{\circ} 36^{\prime} \mathrm{E}$ ), lies in Rasuwa district, central Nepal (Fig. 1). It is a debris-free glacier which lies near Khymjung Glacier, Langtang Valley. The highest and lowest altitudes of the glacier are 5749 and $5128 \mathrm{~m}$ (Advanced Spaceborne Thermal Emission and Reflection Radiometer digital elevation model (ASTER DEM, 2010, $30 \mathrm{~m}$ resolution, downloaded from http://gdex.cr.usgs.gov/gdex/)), respectively. Its area is $1.61 \mathrm{~km}^{2}$. It has a widespread shape and gentle slope $\left(22^{\circ}\right)$ facing southwest (Fujita and others, 1998). A hypsograph of Yala Glacier shows that most of the glacier area lies in the altitude range 5200-5350 ma.s.l.

Analysis of temperature and precipitation gradients is carried out in Langtang Valley, Rasuwa district. It is a glacierized catchment with both debris-free and debriscovered glaciers. It is located to the north of Kathmandu and shares a border with Tibet on the northern side.

\section{DATA AND METHODS}

\subsection{Temperature gradients}

Six temperature sensors are established at Chilime Hydropower, Lama Hotel, Langtang, Kyangjing, Jathang and Numthang at elevations of 1396, 2492, 3539, 3857, 3875 and $3981 \mathrm{~m}$ a.s.l., respectively. Automatic weather stations (AWS) are set up at Kyangjing Base House (' $\mathrm{BH}^{\prime}$, hereafter) and Yala Glacier base camp ('BC', hereafter) at 3857 and 5100 m a.s.l., respectively (Fig. 2).

Hourly data recorded by the temperature sensors are used for analysis. The data from all the temperature loggers are available from 6 May to 27 September 2012 (referred to as 'all data' from now on). The data are divided into period 1 (6 May-16 June 2012), period 2 or monsoon (17 June- 


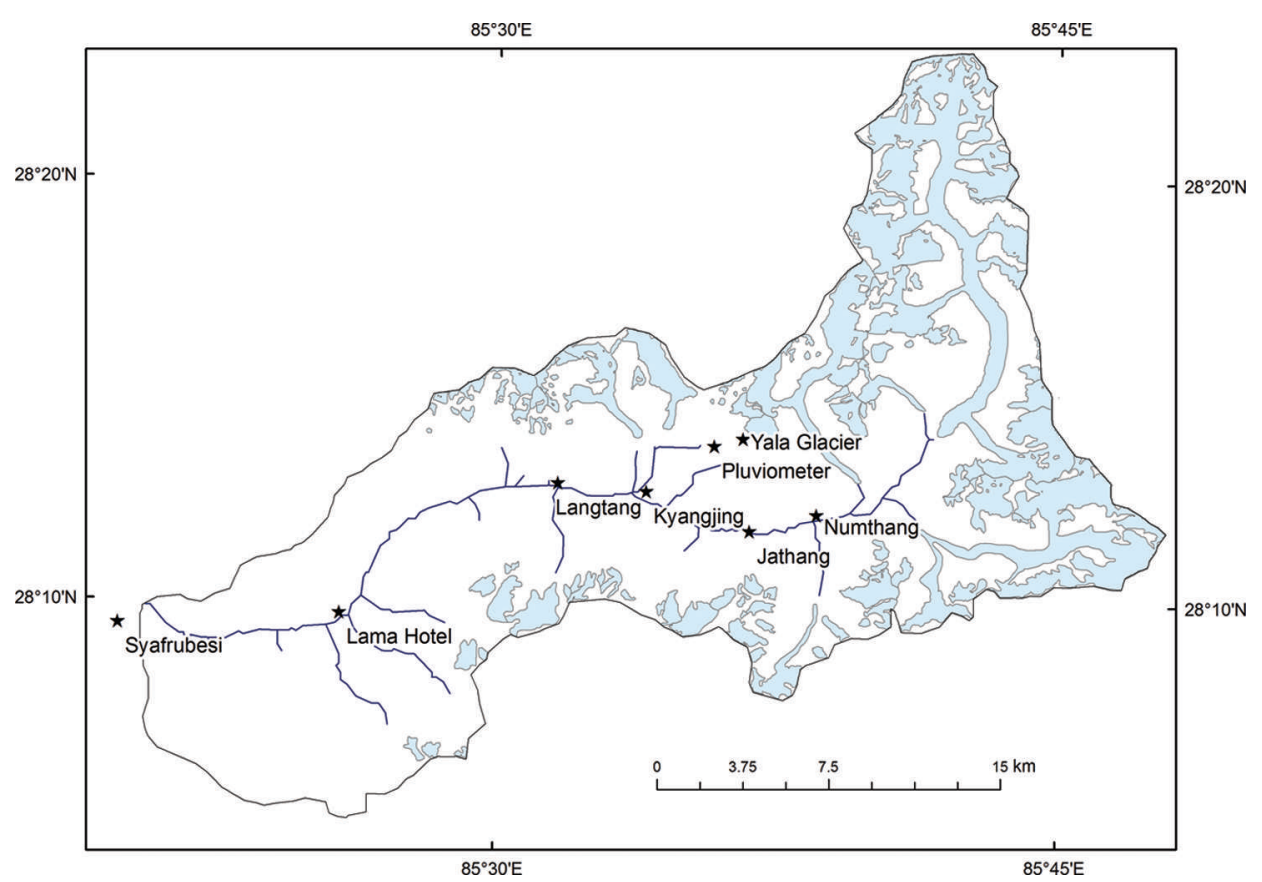

Fig. 2. Map of Langtang Valley. Blue parts denote glaciers based on Bajracharya and others (2011). Stars denote the meteorological stations installed in this study.

19 September 2012) and period 3 (20-27 September 2012). Regression temperature lapse rate during periods $1-3$ is calculated for the entire valley floor (1396-3981 ma.s.l.) and the upper valley floor (3539-3981 ma.s.I.).

Hourly temperature data from the two AWS at BH and $\mathrm{BC}$ are used to calculate the temperature lapse rate between $\mathrm{BH}$ and $\mathrm{BC}$ which is found to be $-0.055^{\circ} \mathrm{C}(100 \mathrm{~m})^{-1}$. This value is used for the extrapolation of air temperature recorded at $\mathrm{BH}$ to estimate air temperature at $\mathrm{BC}$. The same lapse rate is applied to estimate accumulation at each site on the glacier. Takahashi and others (1987) calculated the lapse rate between $\mathrm{BH}$ and $\mathrm{BC}$ to be $-0.06^{\circ} \mathrm{C}\left(100 \mathrm{~m}^{-1}\right)$, which was corrected to $-0.057^{\circ} \mathrm{C}\left(100 \mathrm{~m}^{-1}\right)$ by Fujita and others (1997).

\subsection{Precipitation gradients}

Six tipping buckets are established at Chilime Hydropower, Lama Hotel, Langtang, Kyangjing, Jathang and Numthang at 1396, 2492, 3539, 3857, 3875 and 3981 ma.s.l., respectively. A pluviometer is set up near Yala Glacier at 4831 ma.s.l. (Fig. 2). Precipitation data recorded at six tipping buckets, a pluviometer near Yala and the AWS at BC from May to October 2012 are used to observe the monthly precipitation amount. The regression lapse rate of precipitation is calculated using these data.

To calculate total solid precipitation at $\mathrm{BC}$, precipitation and temperature data recorded at the AWS at BC from 8 May to 3 November 2012 are used. A relation between air temperature and percentage of snowfall as derived in Kayastha and others (2005) is used to separate snow and rain from precipitation amount. According to the relation, all precipitation is considered as snow when the temperature is $0^{\circ} \mathrm{C}$ or $<0^{\circ} \mathrm{C}$; as rain when the temperature is equal to or higher than $3.6^{\circ} \mathrm{C}$; and as a mixture of snow and rain at $0-3.6^{\circ} \mathrm{C}$.

To estimate the amount of solid precipitation at BC from 10 November 2011 until 7 May 2012, precipitation data collected at $\mathrm{BH}$ are used and values are extrapolated to $\mathrm{BC}$ using the relation $P_{\mathrm{BC}}=1.43 \times P_{\mathrm{BH}}$, where $P_{\mathrm{BH}}$ is the precipitation recorded at $\mathrm{BH}$ and $\mathrm{P}_{\mathrm{BC}}$ is the precipitation estimated at BC. This relationship is established based on observation of precipitation data collected at $\mathrm{BH}$ and $\mathrm{BC}$ from 15 June to 15 September 2012. No altitudinal gradient of precipitation amount was assumed on the glacier since the altitude range of the glacier is small.

\subsection{Diurnal cycle of temperature and precipitation}

Temperature and precipitation data recorded at Syafrubesi, Lama Hotel, Langtang, Kyangjing, Jathang and Numthang from 6 May to 27 September 2012 are used to observe the diurnal cycle of temperature and precipitation at these stations.

\subsection{Mass balance}

Mass-balance measurements at six stakes on Yala Glacier, at varying elevations below 5250 ma.s.l., have been carried out by the CMP since November 2011. Other stakes, installed by Chinese and Japanese scientists ('Chinese and Japanese stakes', hereafter), above this elevation are also measured and used in this study. Meteorological variables recorded by the AWS set up at $\mathrm{BC}$ are used to estimate the amount of precipitation at BC. CMP stakes, Chinese and Japanese stakes were measured again on 3 November 2012. A representative area of the glacier, a transect of the glacier, studied by Fujita and others (1998), is considered for the mass-balance calculation (Fig. 1).

In this study, specific mass balance (mw.e.) is calculated using density profiles obtained at each site by snow-pit analysis on 10 and 11 November 2011 and 3 November 2012. The density of ice used was assumed to be $870 \mathrm{~kg} \mathrm{~m}^{-3}$ (Fujita and others, 1998).

For each stake on the glacier, the amount of ablation is calculated by subtracting the estimated accumulation from the observed mass balance. Extrapolation of the specific mass balance observed at stakes at 5244, 5317 and $5444 \mathrm{~m}$ a.s.l. is used to estimate the equilibrium-line altitude 
Table 1. Mean lapse rate calculated for the entire valley floor and upper valley floor

\begin{tabular}{|c|c|c|c|}
\hline $\begin{array}{l}\text { All data } \\
\text { (6 May-27 Sep) }\end{array}$ & $\begin{array}{c}\text { Period } 1 \\
\text { (6 May-16 Jun) }\end{array}$ & $\begin{array}{c}\text { Monsoon } \\
\text { (17 Jun-19 Sep) }\end{array}$ & $\begin{array}{c}\text { Period } 3 \\
(20-27 \text { Sep) }\end{array}$ \\
\hline${ }^{\circ} \mathrm{C} \mathrm{m}^{-1}$ & ${ }^{\circ} \mathrm{Cm}^{-1}$ & ${ }^{\circ} \mathrm{Cm}^{-1}$ & ${ }^{\circ} \mathrm{Cm}^{-1}$ \\
\hline \multicolumn{4}{|c|}{ Entire valley floor (1396-3981 ma.s.I.) } \\
\hline-0.0050 & -0.0063 & -0.0045 & -0.0053 \\
\hline \multicolumn{4}{|c|}{ Upper valley floor (3539-3981 m a.s.I.) } \\
\hline-0.0054 & -0.0063 & -0.0050 & -0.0068 \\
\hline
\end{tabular}

(ELA) and the specific mass balance in the accumulation region of a representative area of the glacier where no stakes are installed. The areal average of mass balance is then calculated.

\section{RESULTS AND DISCUSSION}

\subsection{Temperature gradients}

Table 1 shows the value of mean lapse rate for the whole valley and for the upper valley. Lapse rate values are always lower during the monsoon than in other periods. Lapse rates for the upper valley are steeper but the correlation values are lower than for the whole valley. Lapse rates are steeper during periods 1 and 3 and lowest during the monsoon period. This implies that solar radiation acts as an important factor for steep lapse rates during periods 1 and 3 as there is less radiation during the monsoon due to the presence of monsoon clouds. The calculated lapse rates are very similar to that calculated by Takahashi and others (1987), which was $0.006^{\circ} \mathrm{C} \mathrm{m}^{-1}$ from July 1985 to July 1986 in the same valley between 3920 and $5090 \mathrm{~m}$ a.s.l.

\subsection{Precipitation gradients}

Cumulative precipitation recorded by six tipping buckets shows that the monsoon began on 17 June ( 7 days delayed compared to the normal day of onset, 10 June) and receded on 20 September (which is the normal retreat day) 2012. The amount of precipitation increased in the lower valley from 1396 ma.s.I. to 2492 ma.s.l. The tipping bucket at Lama Hotel received the maximum amount of rainfall in the valley. Higher up, the amount of precipitation decreases in the valley up to $3875 \mathrm{~m}$ a.s.l. Above this elevation, the amount of monthly precipitation starts to increase again (Fig. 3).

The regression lapse rate of monthly precipitation calculated from June to September 2012 shows that the monthly precipitation amount in the valley increases at a rate of $15 \mathrm{~mm}(100 \mathrm{~m})^{-1}$ from 1396 to $2492 \mathrm{~m}$ a.s.l. It decreases at a rate of $24 \mathrm{~mm}(100 \mathrm{~m})^{-1}$ from 3539 to $3875 \mathrm{~m}$ a.s.l. It starts to increase again at $6 \mathrm{~mm}(100 \mathrm{~m})^{-1}$ from 3981 to $5100 \mathrm{~m}$ a.s.l. This increase in the amount of precipitation with altitude above $3981 \mathrm{~m}$ a.s.I. is consistent with the results obtained from meteorological observations in Langtang Valley carried out in the past (Seko, 1987; Fujita and others, 1997). This could be due to convective precipitation associated with mesoscale thermal circulation in the valley, as suggested by Seko (1987).

\subsection{Diurnal cycle of temperature and precipitation}

There is a significant difference between day and night temperatures at all six stations. Precipitation events are

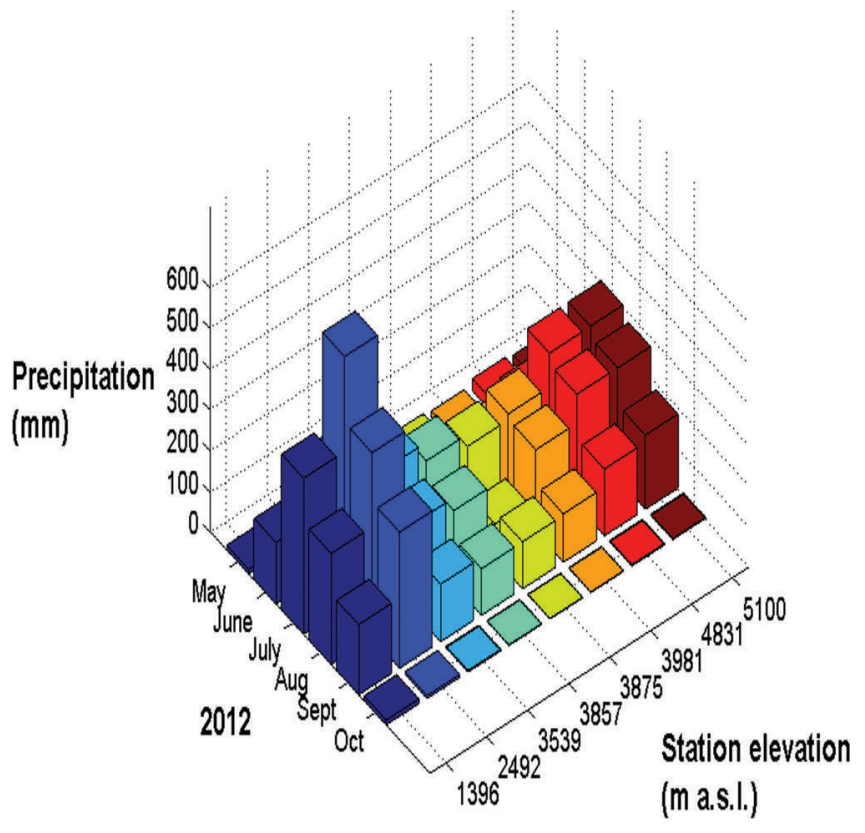

Fig. 3. Monthly precipitation recorded at different elevations in Langtang Valley from May to October 2012.

common during the night and much less so during the day at all stations. Most precipitation events occur after 15:00 and before 08:00. Nocturnal precipitation is due to nocturnal convection in the mountain valleys in Nepal caused by continuous migration of humid air mass due to up-valley winds and downslope wind by radiative cooling (Ohata and others, 1981). Diurnal cycles of temperature are identical for stations in the upper valley. Daytime temperature rises above $20^{\circ} \mathrm{C}$ and $15^{\circ} \mathrm{C}$ at Syafrubesi and Lama Hotel, respectively, but remains below $15^{\circ} \mathrm{C}$ in the upper valley. Ueno and others (1990) also studied the characteristics of diurnal variation of the precipitation in the valley from mid-August to the beginning of October in 1987. They also found similar results and classified three types of dominant precipitation pattern: maximum precipitation usually occurred from early evening until midnight; the other two types occurred from morning (07:00-08:00) to afternoon (14:00-16:00) and from late night (00:00-02:00) to early morning (05:00-06:00).

\subsection{Mass balance}

The calculated mass balance of Yala Glacier from 10 November 2011 to 3 November 2012 is -0.89 m w.e. The estimated ELA is $5455 \mathrm{~m}$ a.s.I. The mass balance is more than twice as negative as that observed by Fujita and others (1998) during the 1996 monsoon season, which was -0.36 mw.e. This confirms that Yala Glacier is in strong negative mass balance recently compared with the 1990s. This is mainly due to increased air temperatures since 1990 and may also be due to increased longwave radiation from the more exposed rock part in the lower area of the glacier. Some stakes show increase in ablation with increasing altitude (Fig. 4), mainly due to their southwest aspect which receives more solar radiation than other stakes.

\section{CONCLUSIONS}

The calculated mass balance of the Yala Glacier transect from 10 November 2011 to 3 November 2012 is $-0.89 \mathrm{~m}$ w.e. The large negative mass balance we have 


\section{Area $\left(\mathrm{km}^{2}\right)$}
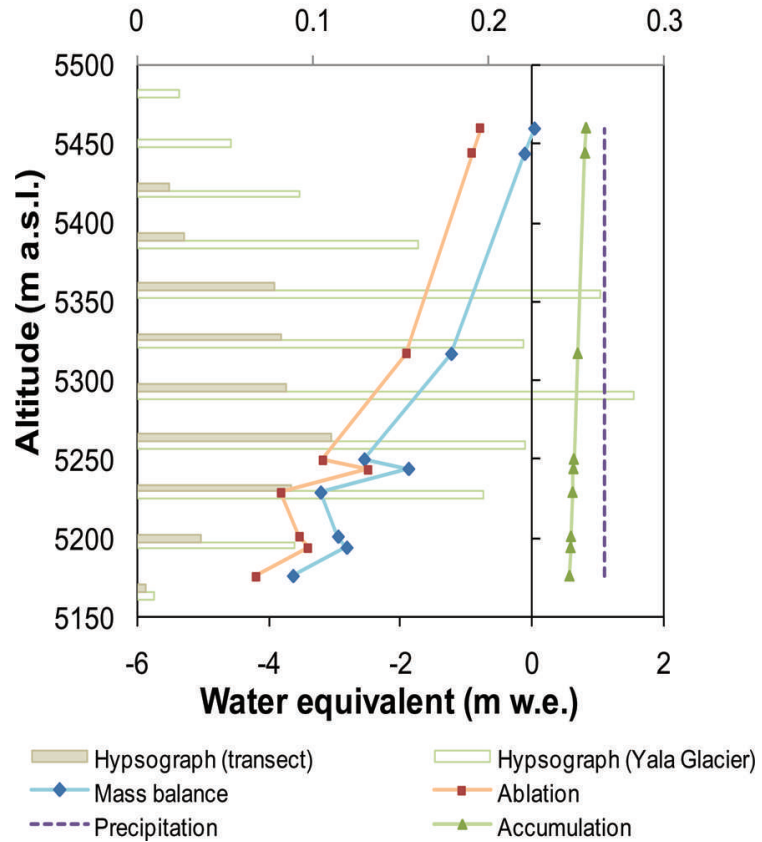

Fig. 4. Hypsograph of Yala Glacier and the observed section of the glacier based on ASTER DEM of $30 \mathrm{~m}$ resolution. Altitudinal distribution of accumulation, mass balance, ablation and precipitation on Yala Glacier from 10 November 2011 to 3 November 2012.

found is consistent with the lower (more negative) end of the range of mass-balance values obtained, using an energy-/ mass-balance model, for recent years up through 2010 and reported by Fujita and Nuimura (2011). Thus, the 2010/11 mass-balance year may be a continuation of a secular trend toward more negative mass balances. Yala Glacier is in strongly negative mass balance in recent years compared with the 1990s. The ELA of the section is calculated at 5455 ma.s.l., which is consistent with a continuation of the rising ELA trend modeled by Fujita and Nuimura (2011) for the more recent years of their study up through 2010 . Distinct diurnal cycles of temperature and precipitation occur at different stations in the valley. The mean temperature lapse rates for the entire valley floor (1396-3981 m a.s.I.) and the upper valley floor (3539-3981 ma.s.I.) are $-0.0050^{\circ} \mathrm{C}$ and $-0.0054^{\circ} \mathrm{C}$, respectively. The lapse rate during the monsoon is lower than during the other observation periods. The monthly precipitation amount in the valley increases at a rate of $15 \mathrm{~mm}(100 \mathrm{~m})^{-1}$ from 1396 to $2492 \mathrm{~m}$ a.s.l. It decreases at a rate of $24 \mathrm{~mm}(100 \mathrm{~m})^{-1}$ from 3539 to 3875 ma.s.l. It starts to increase again at a rate of $6 \mathrm{~mm}(100 \mathrm{~m})^{-1}$ from 3981 to $5100 \mathrm{~m}$ a.s.l. These conclusions are, however, just the preliminary results of a comprehensive scientific study initiated by the CMP which aims to yield multi-year hydrological, meteorological and glacio-hydrological observations in the glacierized Langtang River basin that can be of great use in determining the eventual state of the cryosphere of the Himalayan region.

\section{ACKNOWLEDGEMENTS}

We are very grateful to the HKH Cryosphere Monitoring Project implemented by the International Centre for Integrated Mountain Development (ICIMOD) and supported by the Norwegian Ministry of Foreign Affairs. We also thank the project partners for help in carrying out this study, including the Himalayan Cryosphere, Climate and Disaster Research Center, Kathmandu University; the Central Department of Hydrology and Meteorology, Tribhuvan University; the Department of Hydrology and Meteorology, Government of Nepal; and the Water and Energy Commission Secretariat, Government of Nepal. We are very grateful to the Third Pole Environment (TPE) Program of the Institute of Tibetan Plateau Research, Chinese Academy of Sciences, and Koji Fujita of Nagoya University, Japan, for providing us with the stake data. We thank the anonymous referees and the editor, D.R. MacAyeal, for constructive comments and suggestions.

\section{REFERENCES}

Ageta $Y$ and 6 others (2001) Study project on the recent rapid shrinkage of summer-accumulation type glaciers in the Himalayas, 1997-1999. Bull. Glaciol. Res., 18, 45-49

Bajracharya SR, Maharjan SB and Shrestha F (2011) Glaciers shrinking in Nepal Himalaya. In Blanco J and Kheradmand $\mathrm{H}$ eds. Climate change - geophysical foundations and ecological effects. Intech, Rijeka, 445-458

Barry RG (1981) Mountain weather and climate. Methuen, London Beniston M (2003) Climatic change in mountainous regions - a review of possible impacts. Climatic Change, 59(1-2), 5-31 (doi: 10.1023/A:1024458411589)

Bolch Tand 10 others (2012) The state and fate of Himalayan glaciers. Science, 336(6079), 310-314 (doi: 10.1126/science.1215828)

Fujita K and Nuimura T (2011) Spatially heterogeneous wastage of Himalayan glaciers. Proc. Natl Acad. Sci. USA (PNAS), 108(34), 14 011-14014 (doi: 10.1073/pnas.1106242108)

Fujita K, Sakai A and Chhetri TB (1997) Meteorological observation in Langtang valley, Nepal Himalaya. Bull. Glacier Res., 15, 71-78

Fujita K, Takeuchi N and Seko K (1998) Glaciological observations of Yala Glacier in Langtang Valley, Nepal Himalayas, 1994 and 1996. Bull. Glacier Res., 16, 75-81

Gardner AS and 15 others (2013) A reconciled estimate of glacier contributions to sea level rise: 2003 to 2009. Science, 340(6134), 852-857 (doi: 10.1126/science.1234532)

Higuchi K (1984) Outline of the Glaciological Expedition of Nepal: Boring Project 1981 and 1982. Bull. Glacier Res., 2, 1-5

Holmlund P, Karlén W and Grudd H (1996) Fifty years of mass balance and glacier front observations at the Tarfala Research Station. Geogr. Ann. A, 78(2-3), 105-114

lida H, Endo Y, Kohshima S, Motoyama H and Watanabe O (1987) Characteristics of snow cover and formation process of dirt layer in the accumulation area of Yala Glacier, Langtang Himal, Nepal. Bull. Glacier Res., 5, 55-62

Jacob T, Wahr J, Pfeffer WT and Swenson S (2012) Recent contributions of glaciers and ice caps to sea level rise. Nature, 482(7386), 514-518 (doi: 10.1038/nature10847)

Kadota T, Seko K and Ageta Y (1993) Shrinkage of glacier AX010 since 1978, Shorong Himal, east Nepal. IAHS Publ. 218 (Symposium at Kathmandu 1992 - Snow and Glacier Hydrology), 145-154

Kadota T, Fujita K, Seko K, Kayastha RB and Ageta Y (1997) Monitoring and prediction of shrinkage of a small glacier in the Nepal Himalaya. Ann. Glaciol., 24, 90-94

Kappenberger G, Steinegger U, Braun LN and Kostka R (1993) Recent changes in glacier tongues in the Langtang Khola basin, Nepal, determined by terrestrial photogrammetry. IAHS Publ. 218 (Symposium at Kathmandu 1992 - Snow and Glacier Hydrology), 95-101

Kargel JS, Cogley JG, Leonard GJ, Haritashya UK and Byers A (2011) Himalayan glaciers: the big picture is a montage. Proc. Natl Acad. Sci. USA (PNAS), 108(36), 14709-14710 (doi: 10.1073/pnas.1111663108)

Kayastha RB, Ageta Y and Fujita K (2005) Use of positive degree-day methods for calculating snow and ice melting and discharge in 
glacierized basins in the Langtang Valley, Central Nepal. In De Jong C, Collins D and Ranzi R eds. Climate and hydrology in mountain areas. Wiley, Chichester

Ohata T, Higuchi K and Ikegami K (1981) Mountain-valley wind system in the Khumbu Himal, East Nepal. J. Meteorol. Soc. Jpn, 59(5), 753-762

Ozawa $\mathrm{H}$ (1991) Thermal regime of a glacier in relation to glacier ice formation. (PhD thesis, Hokkaido University)

Raup B, Racoviteanu A, Khalsa SJS, Helm C, Armstrong R and Arnaud Y (2007) The GLIMS geospatial glacier database: a new tool for studying glacier change. Global Planet. Change, 56(1-2), 101-110 (doi: 10.1016/j.gloplacha.2006.07.018)

Rignot E, Velicogna I, Van den Broeke MR, Monaghan A and Lenaerts J (2011) Acceleration of the contribution of the Greenland and Antarctic ice sheets to sea level rise. Geophys. Res. Lett., 38(5), L05503 (doi: 10.1029/2011GL046583)

Seko K (1987) Seasonal variation of altitudinal dependence of precipitation in Langtang valley, Nepal Himalayas. Bull. Glacier Res., 5, 41-47

Seko K and Takahashi S (1991) Characteristics of winter precipitation and its effect on glaciers in the Nepal Himalayas. Bull. Glacier Res., 9, 9-16
Shepherd A and 46 others (2012) A reconciled estimate of ice-sheet mass balance. Science, 338(6111), 1183-1189 (doi: 10.1126/ science.1228102)

Shiraiwa T, Ueno K and Yamada T (1992) Distribution of mass input on glaciers in the Langtang Valley, Nepal Himalayas. Bull. Glacier Res., 10, 21-30

Takahashi $S$ and 7 others (1987) Meteorological features in Langtang valley, Nepal Himalayas, 1985-1986. Bull. Glacier Res., 5, 35-40

Ueno K and Yamada T (1990) Diurnal variation of precipitation in Langtang valley, Nepal Himalayas. Bull. Glacier Res., 8, 93-101

Ueno K, Shiraiwa T and Yamada T (1993) Precipitation environment in the Langtang Valley, Nepal Himalayas. IAHS Publ. 218 (Symposium at Kathmandu 1992 - Snow and Glacier Hydrology), 207-219

Watanabe O and Higuchi K (1987) Glaciological studies in Asiatic highland region during 1985-1986. Bull. Glacier Res., 5, 1-10 Yamada T (1989) An outline of Glaciological Expedition of Nepal: Langtang Himal Project 1987-88. Bull. Glacier Res., 7, 191-193

Yamada T and 7 others (1992) Fluctuations of the glaciers from the 1970s to 1989 in the Khumbu, Shorong and Langtang regions, Nepal Himalayas. Bull. Glacier Res., 10, 11-19 